\title{
KAJIAN POTENSI PERKEBUNAN KELAPA MELALUI \\ HILIRISASI PENGEMBANGAN INDUSTRI VCO \\ DIKAWASAN PEDESAAN BATU AMPAR \\ KABUPATEN KUBU RAYA
}

\author{
MUFLIHAH RAMADHIA \\ Politeknik Negeri Pontianak \\ REVI SESARIO \\ Politeknik Negeri Pontianak
}

\begin{abstract}
This research provides a more accurate picture of information in the possibility of developing a coconut commodity in the core bussines in rural Batu Ampar area, and to know the information about investment needs of the possibility efforts in prospective through the development of coconut as a simple industrial activity processing Virgin Coconut Oil, in the form of pre Feasibility Industry Virgin Coconut Oil (VCO) to be develop into core bussines rural Batu Ampar area. The potential opportunities for developed of downstream coconut industry in the processed product industry in the form of VCO that provides value added products to improve the welfare of people in the rural area of Batu Ampar. Minimize the risk of business failure and provide profitable business opportunities that provide benefit for the community economy and the sustainable growth in the long term. The approach in research is done with opportunity analysis, production trials and using financial analysis.

Keywords : Coconut, Industry Virgin Coconut Oil (VCO), Financial Analysis, Business Feasibility
\end{abstract}




\section{PENDAHULUAN}

Salah satu langkah awal menunjang pengembangan kawasan pedesaan, adalah menentukan jenis komoditi unggulan yang akan dikembangkan sebagai core bussines kawasan. Secara umum penentuan komoditi lebih mudah dilakukan pada kondisi komoditi homogen yang diusahakan oleh masyarakat dibandingkan dengan jenis komoditi yang beragam. Komoditi homogen, berarti hanya terdapat satu komoditi unggulan yang diusahakan oleh sebagian besar penduduk, di samping komoditi lainnya yang bersifat pelengkap kebutuhan penduduk setempat.Salah satu wilayah yang dimasukan dalam rencana pengembangan kawasan pedesaan adalah di Kecamatan Batu Ampar.

Kawasan Pedesaan Kecamatan Batu Ampar terbagi atas dua tema rencana pengembangan kawasan Pedesaan yaitu Kawasan Pedesaan Pesisir Padang Tikar dan Kawasan Pedesaan Pesisir Pantai Batu Ampar. Secara umum potensi kawasan pedesaan di dua kawasan tersebut identik yaitu sektor perikanan, perkebunan dan pertanian campuran. Batasan lain pengembangan kawasan pedesaan di wilayah ini, adalah sebagian wilayahnya yang masuk dalam areal kawasan hutan konservasi, sehingga terdapat pembatas untuk mengembangkan kawasan potensialnya.

Komoditas unggulan yang ada dikawasan tersebut, lebih lanjut dijadikan menjadi tema besar dalam pengembangan kawasan serta core business dan business plan. Tema pengembangan kawasan pedesaan di Kecamatan Batu Ampar sebagai berikut :

1. Kawasan Pedesaan Pesisir Padang Tikar, meliputi, desa Baru Ampar, desa Padang Tikar Satu, desa Padang Tikar Dua, desa Tasik Malaya, desa Sungai Besar, desa Sungai Jawi, desa Ambarawa, dan desa Tanjung Harapan.

2. Kawasan Pedesaan Pesisir Pantai Batu Ampar, meliputi, desa Nipah Panjang, desa

Batu Ampar, desa Teluk Nibung, desa Sungai Kerawang, desa Sumber Agung dan Desa Muara Tiga.

Berdasarkan data kegiatan ekonomi produktif pengolahan lahan eksisting kawasan pedesaan di Batu Ampar yang diusahakan sebagai perkebunan kepala oleh masyarakat (Bappeda Kabupaten Kubu Raya, 2019). Sebagai wilayah kepulauan yang keseluruhan dari panjang garis pesisir pantainya mencapai $194 \mathrm{~km}$, potensi komoditi kepala di 
kawasan Pedesaan ini sangat melimpah. Selain itu karakteristik tanah sangat sesuai untuk dikembangkan komoditi kelapa. Diperkirakan luas perkebunan kelapa di Kabupaten Kubu Raya seluas 8.661 Ha, dan menjadi sumber penghasilan sekitar 17 ribu keluarga petani dan dalam bentuk kebun usaha rakyat.

Kecamatan Batu Ampar salah satu potensi dan keunggulan wilayahnya adalah kelapa dalam, yang saat ini diperkirakan sangat memungkinkan di jadikan industri pengolahan berbasis masyarakat. Sebagaimana layaknya daerah pesisir, karakteristik komoditi utama yang diusahakan oleh sebagian besar penduduk di kawasan pedesaan ini adalah komoditi kelapa yang sampai saat ini hanya memberikan dampak ekomomi yang masih kecil.

Oleh karena itu, untuk meningkatkan nilai tambah dari produk kelapa yang selama ini dijual oleh petani dalam bentuk kelapa butiran ataupun kopra di kawasan pedesaan, perlu dilakukan untuk mengembangkan komoditi kelapa menjadi komoditi lainnya bernilai ekonomis tinggi. Kajian hulu-hilir komoditi unggulan yang akan dilakukan kajian ini lebih diarahkan pada pengolahan lebih lanjut kelapa dalam bentuk pengolahan VCO, dengan pertimbangan dapat diandalkan menjadi core bussines kawasan pedesaan yang berdampak pada pengembangan hulu dan hilir kawasan secara keseluruhan.

\section{KAJIAN LITERATUR}

\section{Virgin Coconut Oil (VCO)}

Virgin Coconut Oil VCO merupakan minyak yang berasal dari buah kelapa (Cocos nucifera) tua segar yang diolah pada suhu rendah $\left(<60{ }^{0} \mathrm{C}\right)$ tanpa proses pemutihan dan hidrogenasi. Proses tersebut membuat minyak kelapa ini dikenal dengan sebutan minyak perawan (Virgin Coconut Oil) atau ada juga yang menyebutnya minyak dara. VCO merupakan minyak kelapa murni yang tahan terhadap panas, cahaya, oksigen dan proses degradasi, karena struktur kimianya tidak mengandung ikatan ganda. Karakteristik lain dari VCO adalah memiliki warna jernih, beraroma lembut dan rasanya gurih. Selain itu VCO mengandung asam - asam lemak jenuh yang tinggi yang menjadikannya tidak mudah tengik.

\section{Kelapa}

Kelapa adalah tanaman asli Indonesia. Kelapa merupakan salah satu tanaman perkebunan yang mampu tumbuh dan berproduksi dengan baik. Hal ini dipengaruhi oleh 
iklim di Indonesia yang sangat cocok untuk pertumbuhan tanaman kelapa. Tanaman kelapa mampu tumbuh dengan baik pada ketinggian $0 \mathrm{~m}-600 \mathrm{~m}$ di atas permukaan laut dengan suhu rata-rata $25{ }^{0} \mathrm{C}$ dan kelembaban udara $80-95 \%$.

Buah kelapa berbentuk bulat lonjong dengan ukuran bervariasi, tergantung pada keadaan tanah, iklim dan varietasnya. Warna kelapa juga bervariasi, mulai dari kuning sampai hijau muda, dan setelah masak berubah menjadi coklat. Struktur buah kelapa terdiri dari sabut (35\%), daging buah (28\%), air kelapa (15\%), tempurung (12\%) serta beberapa bagian lainnya. Hampir semua bagian kelapa dapat dimanfaatkan. Daging buah kelapa berwarna putih dengan ketebalan cukup bervariasi, tergantung pada umur dan varietas kelapa. Umumnya semakin tua buah kelapa, daging buahnya akan semakin tebal. Pada pembuatan VCO, semakin baik mutu kelapa yang digunakan, kualitas VCO yang dihasilkan juga semakin baik dan rendemennya semakin tinggi.

\section{Kelayakan Usaha}

Dalam menjalankan usaha baik itu yang sudah berjalan maupun berencana untuk mengembangkannya, seorang pelaku usaha harus dapat memperhitungkan terlebih dahulu baik buruknya usaha tersebut. Oleh karena itu sebelum melakukan usaha atau mengembangkan usaha, perlu dilakukan adanya studi kelayakan untuk mengetahui apakah investasi yang akan dijalankan layak atau tidak. Untuk pengertian Studi Kelayakan Bisnis (SKB) itu sendiri ada beberapa pengertian diantaranya:

1. Menurut Umar (2005:8) Studi kelayakan bisnis merupakan penelitian terhadap rencana bisnis yang tidak hanya menganalisis layak atau tidak layak bisnis dibangun, tetapi juga pada saat dioperasionalkan secara rutin dalam rangka pencapaian keuntungan yang maksimal untuk waktu yang tidak ditentukan.

2. Menurut Husnan (2014) studi kelayakan bisnis adalah penelitian tentang dapat tidaknya suatu proyek investasi dilaksanakan dengan berhasil. Keberhasilan bisa diartikan lebih luas atau lebih terbatas yang terutama dipergunakan oleh pihak swasta yang lebih berminat tentang manfaat ekonomis suatu investasi.

\section{Analisis Potensi Industri}

Industri dapat diartikan sebagai kumpulan perusahaan atau organisasi yang melakukan kompetisi secara langsung dipasar dengan produk atau jasa yang sejenis. 
Industri dapat didefinisikan dalam empat dimensi yaitu dimensi produk, dimensi pengunjung, dimensi geografi, dan dimensi tahapan dalam jalur produksi- distribusi (de Kluyver, 2006). Analisis industri akan melihat hubungan antar perusahaan terhadap hubungan vertikal ataupun hubungan horisontal dengan pihak-pihak luar. Sehingga akan terlihat faktor-faktor dari hubungan hubungan tersebut yang mempengaruhi kemampuan perusahaan dalam menjaga relasi.

\section{Aspek Lokaksi}

Penelitian mengenai lokasi ini meliputi berbagai pertimbangan, apakah harus dekat dengan bahan baku, tenaga kerja, akses jalan, kemudahan listrik, kebersihan sumber air, atau pertimbangan lainnya. Setelah ditelitinya pertimbangan tersebut, nantinya akan dipilih lokasi terbaik yang dapat mengoptimalkan kinerja dari perusahaan serta memaksimalkan laba yang akan didapat (Kasmir dan Jakfar, 2009).

\section{Aspek Teknis Pegembangan Indsusti}

Aspek ini bertujuan untuk meyakini apakah secara teknis dan pilihan teknologi perencanaan yang telah dilakukan dapat dilaksanakan secara layak atau tidak layak (Husnan dan Suwarsono, 2000). Pada aspek teknis dan teknologis dipaparkan beberapa faktor, yaitu penentuan kapasitas produksi, tata letak tempat usaha, pemilihan mesin, peralatan dan teknologi untuk produksi (Umar, 2001).

\section{Aspek Pasar dan Pemasaran}

Pasar dan pemasaran merupakan dua sisi yang tidak dapat dipisahkan satu sama lain. Pasar dan pemasaran mempunyai tingkat ketergantungan yang tinggi dan saling mempengaruhi satu sama lainnya. Pasar dapat diartikan suatu kumpulan atau himpunan dari para pembeli, baik pembeli nyata (memiliki minat, pendapatan dan akses) maupun pembeli potensial (memiliki minat tetapi tidak memiliki kemampuan pendapatan dan akses) atas suatu barang atau jasa.

\section{Aspek Keuangan (Kelayakan Investasi)}

Aspek keuangan merupakan aspek yang digunakan untuk menilai keuangan perusahaan secara keseluruhan. Aspek ini sama pentingnya dengan aspek lainnya, bahkan ada beberapa pengusaha menganggap justru aspek inilah yang paling utama untuk dianalisis karena dari aspek ini tergambar jelas hal-hal yang berkaitan dengan keuntungan perusahaan, sehingga merupakan salah satu aspek yang sangat penting untuk 
diteliti kelayakannya. Tujuan dari aspek keungan ini adalah untuk membandingkan pengeluaran dengan pendapatan, seperti ketersediaan dana, kemampuan usaha untuk membayar kembali dana tersebut dalam waktu yang telah ditentukan dan menilai apakah usaha akan berkembang terus.

Adapun kriteria yang biasa digunakan sebagai alat ukur untuk menentukan kelayakan suatu usaha yaitu dengan pendekatan Payback Period (PP), Average Rate of Return (ARR), Net Present Value (NPV), Internal Rate or Return (IRR), Profitability Index (PI), Break Event Point (BEP) dan Sensitivitas

\section{Pengertian Investasi}

Istilah investasi merupakan penanaman modal (modal tetap maupun tidak tetap) yang digunakan dalam proses produksi untuk memperoleh keuntungan suatu perusahaan. Sedangkan menurut Downes dan Goodman, investasi adalah investasi keuangan dimana seorang investor menanamkan uangnya dalam bentuk usaha dalam waktu tertentu dari setiap orang yang ingin memperoleh laba dari keberhasilan pekerjaannya.

Semua orang pasti dalam melakukan investasi tujuan yang paling utama yaitu mencari keuntungan yang sebesar-besarnya dan mencari cara bagaimana meminimalisir adanya resiko. Oleh karena itu dalam melakukan investasi dalam usaha apapun kita harus menekuninya dan harus mengetahui prospek kedepan dari usaha yang akan kita jalani tersebut.

\section{METODE PENELITIAN}

\section{Survey}

Pengumpulan data dan informasi yang diperlukan sebagai dalam pekerjaan ini dilakukan dengan cara sebagai berikut:

a. Survey Institusional/Instansional, yang ditujukan untuk mendapatkan data sekunder yang dimiliki oleh institusi/ lembaga, instansi-instansi terkait, baik pemerintah maupun swasta.

b. Observasi Lapangan, yang berupa pengamatan atau peninjauan langsung terhadap obyek pekerjaan.

c. Teknik Wawancara dan atau Kuesioner, umumnya teknik ini dilakukan apabila data dan atau informasi sebagai bahan masukan tidak terdapat dalam data 
sekunder

\section{Pengolahan Data}

Mempersiapkan data mentah (row data) menjadi data yang siap dianalisis dan menentukan metode pengolahan data untuk mencapai tujuan dan sasaran kegiatan ini.

a) Analisa Diskriptif.

Analisa disktiptif dilakukan untuk memberikan gambaran terhadap data primer hasil verifikasi dan analisa situasi kondisi wilayah, yang dituangkan dalam kajian.

b) Analisa Kuantitatif.

Analisa kualitatif dilakukan dengan menggunakan beberapa metode, meliputi:

1) Kajian dan Analisis Potensi Dan Lokasi industri : Analisis dilakukan dengan maksud untuk menggambarkan lokasi dan penempatan yang pantas untuk industri yang akan dibangun. Penekanan kunci dalam pengkajian ini yaitu lokasi, kondisi lokal (fisik dam infrastruktur sosial ekonomi), kebijakan publik, bahan baku dan orientasi pasar, kondisi geografis dan aspek lainnya yang relevan dengan kajian.

2) Kajian dan Analisis Aspek Teknis Pengembangan Industri: Analisis dilakukan dengan maksud untuk mendapatkan informasi tentang kesiapan lingkungan dan sosial, serta analisa ketersediaan dan kebutuhan tenaga kerja. Dalam kajian ini ditekankan pula program produksi, program suplai bahan baku serta teknologi yang akan digunakan.

3) Kajian dan Analisis Pemasaran Produk: Analisis ini ditekankan pada aspek kondisi pasar dan pemasaran produk yang akan dikembangkan, yang kemudian menjadi dasar (benchmark) rencana peningkatan produksi dan penjualan (Kondisi pasar dan pemasaran produk).

4) Kajian dan Analisis Kelayakan Investasi: Financial, Structure Analysis, Cost Estimation Analysis, Financial and Profitability Analysis.

Aspek finansial yang dianalisa mencakup:

a. Pay Back Period (PP). Pay Back Period dapat diartikan sebagai jangka waktu kembalinya investasi yang telah dikeluarkan, melalui keuntungan yang diperoleh dari suatu proyek yang telah direncanakan:

$$
\text { Payback Period }=\frac{\text { n+(a-b) }}{(\mathrm{c}-\mathrm{b})}
$$


Dimana

a = Jumlah investasi mula-mula

$\mathrm{b}=$ Jumlah kumulatif arus kas pada tahun ke $-\mathrm{n}$

c $\quad=$ Jumlah kumulatif arus kas pada tahun ke $n+1$

$\mathrm{n}=$ Tahun terakhir

b. Net Present Value ( NPV). NPV merupakan selisih antara Present Value dari benefit dan Present Value dari biaya suatu proyek, dikatakan layak secara finansial jika mempunyai NPV lebih besar dari nol. NPV dihitung dengan rumus sebagai berikut:

\begin{tabular}{|ll|l}
$\mathrm{NPV}=$ & $\underline{\mathrm{Bt}-\mathrm{Ct}}$ \\
$\mathrm{t}=0$ & $(1+\mathrm{i})^{\mathrm{t}}$
\end{tabular}$\quad \begin{aligned} & \mathrm{Bt}=\text { Keuntungan Kotor proyek tahun ke- } \mathrm{C} \\
& \mathrm{Ct}=\text { Pengeluaran kotor Proyek tahun ke-t } \\
& \mathrm{n}=\text { Umur Ekonomi Proyek } \\
& \mathrm{i}=\text { Tingkat Bunga Dalam Persen }\end{aligned}$

c. Internal Rate Of Return. IRR yang merupakan indikator tingkat efisiensi dari suatu investasi. Suatu proyek/investasi dapat dilakukan apabila laju pengembaliannya lebih besar daripada laju pengembalian apabila melakukan investasi IRR merupakan nilai discount rate (i) yang membuat NPV sama dengan nol. Persamaan IRR adalah sebagai berikut:

$$
I R R=i_{1}+\left[\frac{N P V_{1}-\left(i_{2}-i_{1}\right)}{N P V_{1}-N_{P V}}\right]
$$

Dimana:

$\mathrm{i}_{1}=$ tingkat suku bunga yang menyebabkan $\mathrm{NPV}_{1}$ bernilai positif

$\mathrm{i}_{2}=$ tingkat suku bunga yang menyebabkan $\mathrm{NPV}_{2}$ bernilai negatif mendekati nol

Penyelesaian persamaan tersebut dilakukan dengan menggunakan metoda trial and error atau dengan teknik penelusuran oleh komputer untuk mencari nilai akar persamaan polinominal dalam i. Kriteria pembanding IRR adalah 
tingkat suku bunga yang berlaku (i) dan jika tingkat bunga perhitungan lebih dari i (I hitung atau IRR >i), maka keputusan yang diambil adalah layak.

d. Profitability Index. (PI) merupakan resiko aktivitas dari jumlah nilai sekarang penerimaan bersih dengan nilai sekarang pengeluaran investasi selama umur investasi, atau metode yang menghitung perbandingan antara present value cash inflow dengan present value initial investment (Sutrisno, 2009:128). Rumus perhitungan PI menurut Kasmir dan Jakfar (2007:163) adalah sebagai berikut:

Rumus yang digunakan dalam Profitability Indeks adalah:

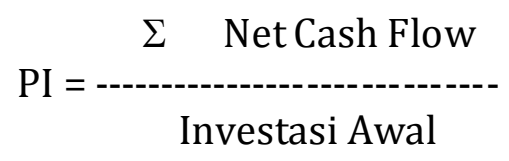

\section{HASIL PENELITIAN DAN PEMBAHASAN}

\section{Gambaran Wilayah Kawasan Pedesaan Batu Ampar Pesisir Kecamatan Batu}

\section{Ampar}

Kawasan Perdesaan Batu Ampar Pesisir di Kabupaten Kubu Raya, Provinsi Kalimantan Barat terletak di Kecamatan Batu Ampar dan diajukan sebagai Kawasan Perdesaan Pertanian Terpadu sebagai tema dalam perencanaan kawasan perdesaannya. Tema Kawasan Perdesaan Pertanian Terpadu yang dimaksud adalah kawasaan yang terdiri dari beberapa desa yang berbatasan secara administrasi dengan memiliki kesamaan potensi pertanian secara luas yaitu adanya integrasi pengembangan sektor pertanian berupa pertanian tanaman pangan, perkebunan, perikanan, dan peternakan. Kawasan perdesaaan Batu Ampar Pesisir terdiri dari 6 desa. Desa tersebut adalah Desa Nipah Panjang, Batu Ampar, Teluk Nibung, Sungai Kerawang, Sumber Agung, dan Muara Tiga. Secara tigas desa terakhir letaknya terpisahkan oleh selat namun secara fisiografi memiliki kesamaan potensi, sehingga dimasukan menjadi satu bagian wilayah pengembangan. Batas-batas administratif kawasan perdesaan Pesisir Batu Ampar adalah sebagai berikut: 


\begin{tabular}{|c|c|c|}
\hline & Sebelah Utara & : Kawasan Perdesaan Kubu Betuah \\
\hline & Sebelah Timur & : Kabupaten Ketapang \\
\hline & Sebelah Barat & Kawasan Perdesaan Pesisir Pantai Padang \\
\hline
\end{tabular}

Tikar

- Sebelah Selatan : Teluk Nuri, Kabupaten Ketapang

Potensi Kesesuaian Sektor Sub Sektor Perkebunan Kawasan Pedesaan Batu Ampar Pesisir

Lahan pekebunan di Kecamatan Batu Ampar sebagian besar ditanami dengan tanaman, karet, kelapa dalam, kelapa hybrida, kelapa sawit, kopi dan pinang dengan masing-masing luas lahan seluas 195 hektar, 7.051 hektar, 720 hektar, 15.024 hektar, 395 hektar,dan 27 hektar. Keseluruhan total luasan lahan yang digunakan untuk 6 komoditi perkebunan tersebut adalah sebesar 23.412 hektar. Kondisi ini menggambarkan bahwa perlu adanya penguatan kembali pada komoditi perkebunan yang dilakukan oleh pemerintah melalui masyarakat dalam meningkatkan kemampuan daerah dalam hal ini desa untuk meningkatkan keunggulan kompetitif wilayah dari sub sektor perkebunan baik dari luas areal yang digunakan maupun jenis komoditi yang ditanam.

Berdasarkan hasil analisis Location Quotient (LQ) yang menggunakan data luas areal komoditas/produksi Komoditas Perkebunan serta menetukan rating prioritas dapat dilihat pada tabel 4.5. LQ dapat dipilah menjadi dua kriteria yaitu LQ > 1 (basis) dan LQ $<1$ (non basis).

\section{Analisis Potensi Industri VCO}

Pengolahan minyak kelapa murni menjadi VCO merupakan proses pengolahan minyak kelapa tanpa proses pemanasan. Bahan baku untuk pembuatan minyak kelapa murni yaitu berupa buah kelapa yang sudah tua atau berumur 11-12 bulan. Buah kelapa yang sudah tua ditandai dengan warna kulit buah atau sabut yang sudah mulai kecokelatan. Peralatan dan sarana pendukung pada pengolahan minyak kelapa murni adalah antara lain pengupas kelapa, parutan, baskom, saringan, penampung (wadah besar), keran, gallon, dan penyaring. 


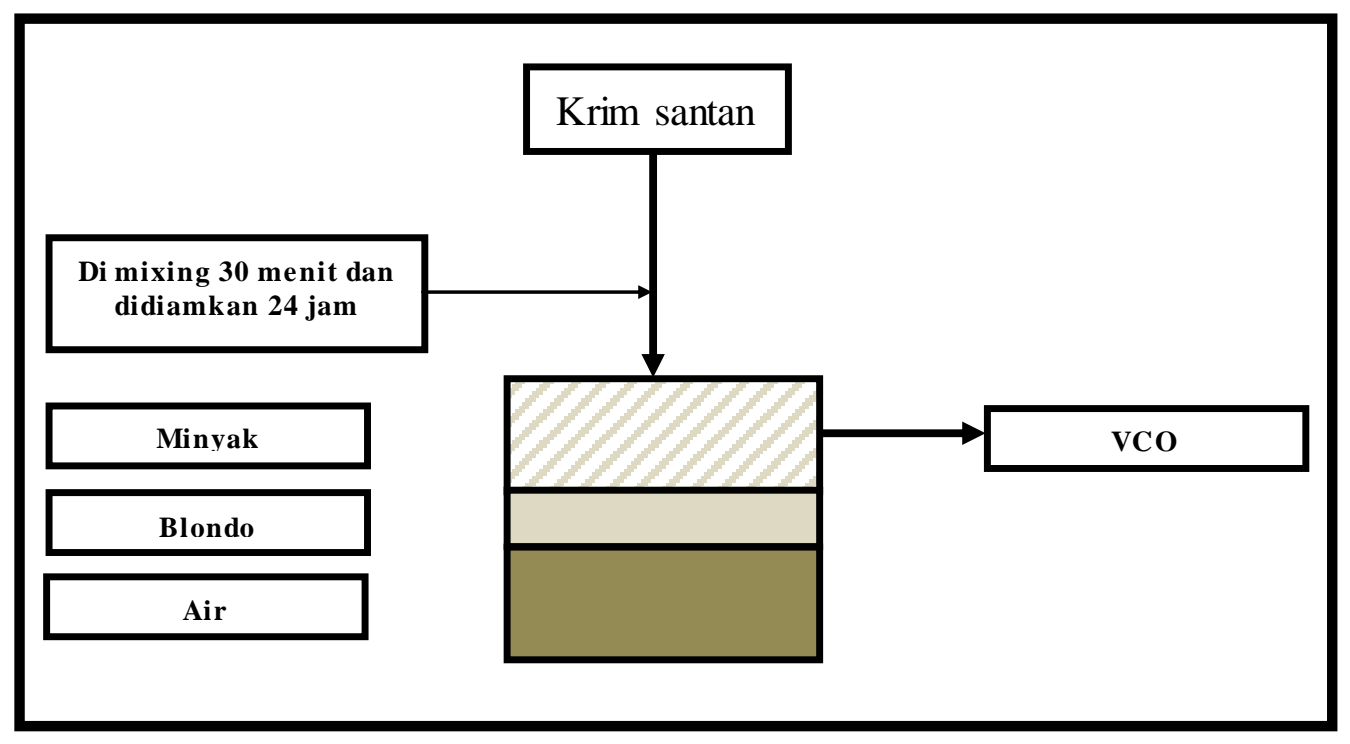

Gambar 4.1 Segmentasi krim santan

\section{Kelayakan Investasi}

1. Kapasitas Produksi

Dengan asumsi bahwa industri minyak kelapa murni yang akan dididirikan memiliki kapasitas produksi 200 liter minyak kelapa murni/hari maka produksi optimum yang dapat dihasilkan memerlukan bahan baku sekitar 2.000-2.200 butir kelapa/hari)

2. Fasilitas Produksi dan Peralatan

Untuk melakukan proses produksi dengan kapasitas 0,2 ton/hari, diperlukan tempat yang terdiri dari tanah dan bangunan yang berukuran $200 \mathrm{~m}^{2}-300 \mathrm{~m}^{2}$. Bangunan untuk pabrik dapat dibentuk sedemikian rupa untuk dapat menampung mesin-mesin dan peralatan lain dalam proses produksi. Ada tiga jenis mesin utama yang digunakan dalam industri pengolahan minyak kelapa. Ketiga mesin tersebut sesuai dengan fungsinya masing-masing, yaitu:

a. Mesin giling untuk menggiling atau memarut daging kelapa segar.

b. Mesin pengering yang digunakan adalah mesin pengering tipe konveyor.

Tujuan dari pengeringan daging kelapa parut adalah memudahkan minyak keluar dari sel dan menginaktifkan enzim serta mikroorganisme tertentu. 
Pengeringan juga berfungsi untuk menguapkan air serta menaikkan keenceran minyak (fluidity).

c. Mesin penggerak untuk menggerakkan mesin pengepress (screw press)

Selain ketiga jenis mesin utama di atas, diperlukan peralatan kerja pendukung lainnya yaitu skop dan drum yang berguna untuk memindahkan potongan daging kelapa dari mesin giling ke mesin pengering. Selain itu, diperlukan juga tangki-tangki untuk menampung dan mengendapkan minyak kelapa yang dihasilkan dan pemipaan atau selang untuk mengalirkan minyak kelapa hasil pengolahan dari satu tangki ke tangki yang lainnya.

\section{Teknologi}

Teknologi yang digunakan adalah teknologi pengolahan minyak kelapa murni dengan proses mekanis. Sementara dari penggunaan mesin dan peralatan, dapat disimpulkan bahwa teknologi pengolahan tersebut tergolong pada taraf sedang (madya) dan dari proses produksi yang akan dihasilkan dapat dikatakan sebagai intensif.

\section{Asumsi dan Parameter Perhitungan}

Beberapa asumsi yang penting dalam mengevaluasi profitabilitas rencana investasi usaha minyak kelapa murni dapat dijelaskan pada Tabel 2. Umur proyek diasumsikan selama 5 tahun dan sisanya umur barang investasi dihitung sebagai pendapatan pada akhir periode (tahun kelima). Lebih lanjut, harga VCO dijual Rp.115.000/liter, sedangkan input utama berupa daging kelapa segar dibeli seharga Rp.1.500 per biji. Kapasitas input pabrik diasumsikan sebesar 5 ton per bulan. Kapasitas optimal sekitar 2 ton dari kapasitas mesin diperkirakan akan tercapai pada tahun ke 6 sampai umur proyek berakhir. 
Tabel 4.1

Dasar Perhitungan Kelayakan Usaha Industri Minyak Kelapa Murni

\begin{tabular}{|c|l|l|c|c|}
\hline No & \multicolumn{1}{|c|}{ Asumsi } & Satuan & $\begin{array}{c}\text { Jumlah/ } \\
\text { nilai }\end{array}$ & Keterangan \\
\hline 1. & Priode Proyek & Tahun & 5 & Umur Ekonomis \\
\hline 3. & Hari produksi per Bulan & Hari & 25 & \\
\hline 4. & Bulan produksi/tahun & Bulan & 12 & \\
\hline 5. & Hari produksi/tahun & Hari & 300 & \\
\hline 6. & Tenaga Kerja : & & & \\
\hline & a.Manajer Umum & orang & 1 & \\
\hline & b.Tenaga kerja produksi & orang & 3 & \\
\hline & c.Tenaga Administrasi & orang & 1 & \\
\hline 7. & Harga : & & & \\
\hline & a.Daging Kelapa Segar & Rp/kg & 2.500 & \\
\hline & b.Minyak kelapa murni & Rp/kg & 115.000 & \\
\hline 8. & Rendaman Output/hari : & & & \\
\hline & a.Minyak & $\%$ & 30 & \\
\hline & b.VCO & Kg & 200 & \\
\hline 9. & Lama Tahun 0 & bulan & 12 & Proses Investasi sampai \\
& & & & pabrik siap \\
\hline 10. & Discout Rate & $\%$ & 16 & \\
\hline
\end{tabular}

Sumber: Hasil Olahan, 2019

5. Komponen Biaya Investasi dan Biaya Operasional

Penjelasan mengenai gambaran biaya investasi dan biaya operasional sebuah usaha pengolahan minyak kelapa murni, tergantung pada kapasitas produksi yang diinginkan. Dengan kapasitas yang diinginkan tersebut, kemudian diperlukan mesin-mesin dan peralatan pendukung lainnya. Sebagai gambaran, investasi sebuah usaha pengolahan minyak kelapa dengan kapasitas input 0,2 ton per hari sebagai berikut:

a. Biaya Investasi/Fixed Cost

Untuk membangun sebuah pabrik minyak kelapa murni dengan kapasitas 0,2 ton per bulan dapat diuraikan pada tabel 4.7 biaya investasi/fixed cost yang diperlukan adalah Rp. 100.218.500,-. Sementara untuk pembangunan bangunan pabrik pengolahan dan aktifitas fisik bangunan lainnya, diasumsikan menggunakan bangunan yang sudah ada, sehingga tidak dihitung sebagai komponen perhitungan investasi. 
Tabel 4.2 Biaya Tetap / Fixed Cost

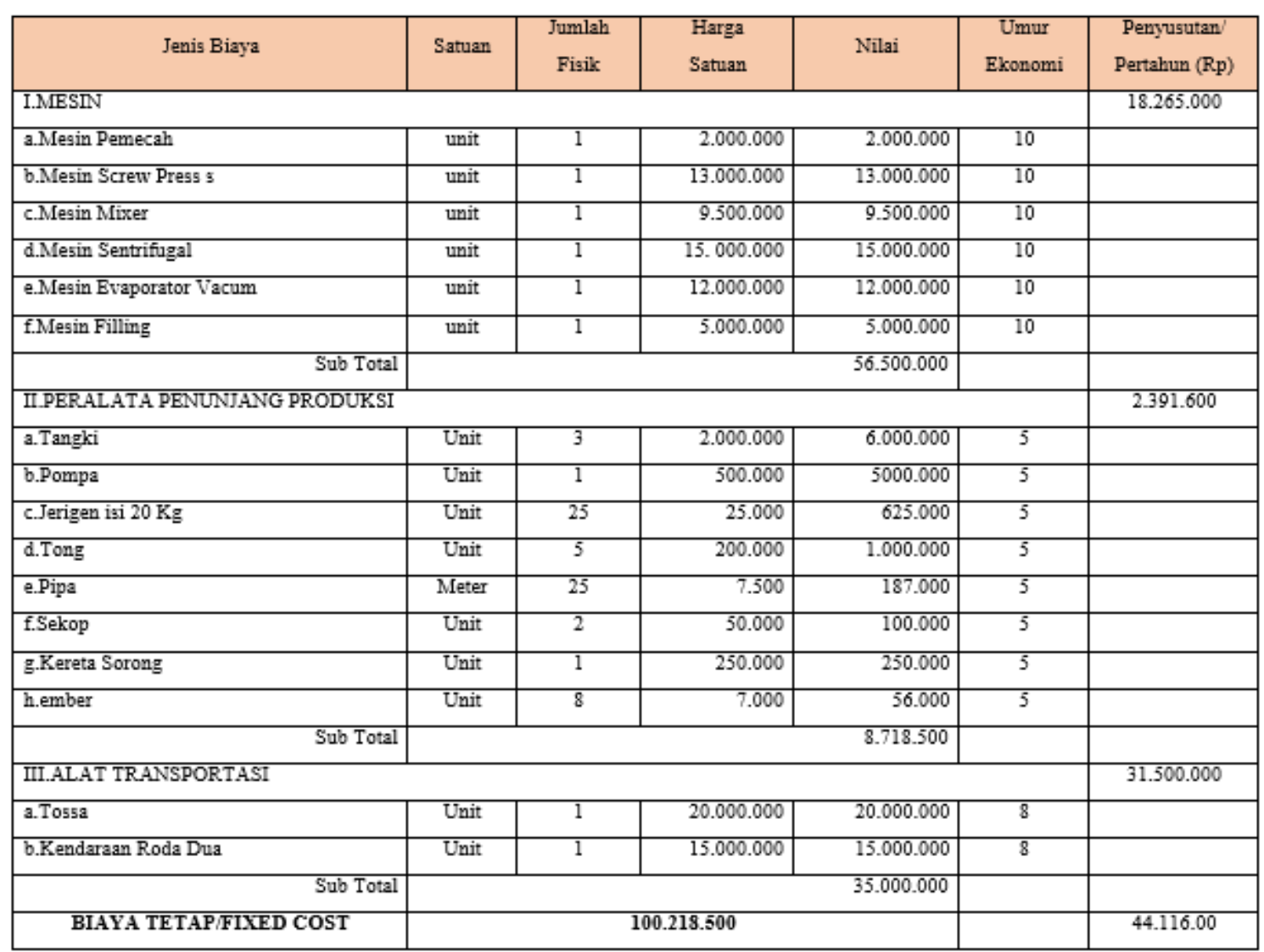

Sumber: Hasil Olahan, 2019

b. Biaya Operasional

Dengan kapasitas 0,2 ton akan dibutuhkan biaya operasional per bulan Rp.7.514,167 atau per tahun sebesar Rp.90.170.000,- Biaya ini terdiri dari komponen biaya bahan baku, biaya tenaga kerja dan overhead cost. Komponen biaya operasional terbesar adalah komponen biaya variabel. Komponen biaya variabel tersebut sebagian besar digunakan untuk pembayaran gaji yang mencapai rata-rata Rp.5.250.000 per bulan. Komponen biaya bahan baku/tahun mencapai $65 \%$ dari total biaya operasional. Tabel 4.8 menjelaskan secara rinci komponen-komponen biaya operasional. 
Tabel 4.3 Biaya Operasional/Variabel Cost Per Tahun

\begin{tabular}{|c|c|c|c|c|}
\hline Jenis Biaya & Satuan & Jumlah & Harga Satuan & Nilai \\
\hline \multicolumn{5}{|l|}{ I.BAHAN BAKU dan Penunjang } \\
\hline a. Daging Kelap̣a & Butir & 5.000 & 2.5000 & 12.500 .000 \\
\hline b.Solar & Liter & 300 & 5.150 & 1.545 .000 \\
\hline c.Bensin & Liter & 250 & 6.500 & 1.625 .000 \\
\hline d.Oli Curah & Drum & 1 & 1.500 .000 & 1.500 .000 \\
\hline e.Botol VCO Uk. $125 \mathrm{ml}$ & Botol & 4.000 & 1.000 & 4.000 .000 \\
\hline Sub Total & \multicolumn{4}{|r|}{21.170 .000} \\
\hline \multicolumn{5}{|l|}{ TENAGA KERJA } \\
\hline a. Manajer Umum & Orang $/$ bln & 1 & 2.000 .000 & 24.000 .000 \\
\hline b.Karyawan Produkgi & Orang/bln & 3 & .750 .000 & 27.000 .000 \\
\hline d.Karyawan Administrasi & Orang/bln & 1 & 1.000 .00 & 12.000 .000 \\
\hline Sub Total & \multicolumn{4}{|r|}{63.000 .000} \\
\hline \multicolumn{5}{|l|}{ III.OVERHEAD COST } \\
\hline a.Listrik & bln & 12 & 500.000 & 6.000 .000 \\
\hline Sub Total & \multicolumn{4}{|r|}{6.000 .000} \\
\hline BIAYA OPERASIONAL/VARIABLE COST & \multicolumn{4}{|c|}{90.170 .000} \\
\hline
\end{tabular}

Sumber hasil olahan, 2019

Gambar 4.4

Rekap Biaya Investasi Per Tahun

\begin{tabular}{|c|c|c|c|c|c|c|}
\hline \multirow[t]{2}{*}{ No } & \multirow[t]{2}{*}{ Jenis Biaya } & \multicolumn{5}{|c|}{ Tahun } \\
\hline & & 2019 & 2020 & 2021 & 2022 & 2023 \\
\hline \multirow[t]{5}{*}{ I. } & Biaya Tetap/Fixed Cost & & & & & \\
\hline & a.Mesin & 56.500 .000 & 56.500 .000 & 56.500 .000 & 62150.000 & 62150.000 \\
\hline & b.Peralatan Transportasi. & 35.000 .000 & 38.500 .000 & 42.350 .000 & 46.585 .000 & 51.243 .500 \\
\hline & c.Peralata Penunjang & 8.718 .500 & 8.718 .500 & 8.718 .500 & 9.590 .350 & 9.590 .350 \\
\hline & Total Biaya Tetap & 100.218 .500 & 103.718 .500 & 107.568 .500 & 118.325 .350 & 122.983 .850 \\
\hline \multirow[t]{5}{*}{ II. } & Biaya Operasional/Variable Cost & & & & & \\
\hline & a. Bahan Baku dan Penunjang & 21.170 .000 & 23.287 .000 & 25.615 .700 & 28.177 .270 & 30.994 .997 \\
\hline & b.Tenaga kerja & 63.000 .000 & 69.300 .000 & 76.230 .000 & 83.853 .000 & 92.238 .300 \\
\hline & d.Overheadcost & 6.000 .000 & 6.600 .000 & 7.260 .000 & 7.986 .000 & 8.784 .600 \\
\hline & Total Biaya Operasional & 87.670 .000 & 96.437 .000 & 106.080 .700 & 116.688 .770 & 128.357 .647 \\
\hline \multicolumn{2}{|c|}{ TOTAL BIAYA } & 190.388 .500 & 202.905 .500 & 216.674 .200 & 238.341 .620 & 255.001 .747 \\
\hline
\end{tabular}

Sumber: hasil olahan, 2019

c. Kebutuhan Dana Untuk Investasi, Modal Kerja dan Kredit

Kebutuhan dana tahun awal keseluruhan untuk mendirikan usaha pengolahan minyak kelapa diperlukan dana sebesar Rp. 154.526.350. Idealnya modal investasi tersebut sebagian dapat didanai oleh bank. Tabel 6.5 menunjukkan 
untuk rencana pembiayaan investasi, biaya berasal dari dana BUMADes sebesar Rp. 42.287.400dan kredit sebesar Rp. 63.431.100atau 40\% dana sendiri dan $60 \%$ dana dari kredit. Sementara itu, modal kerja juga sama dengan kompisisi yang sama.

\section{Tabel 4.5}

Kebutuhan Dana Proyek untuk Investasi dan Modal Kerja Setahun

\begin{tabular}{|c|l|c|}
\hline No & \multicolumn{1}{|c|}{ Biaya Rincian Proyek } & Total Biaya \\
\hline I & 1. Kebutuhan Modal Investasi & $\mathbf{1 0 5 . 7 1 8 . 5 0 0}$ \\
\hline & Dana Investasi yang bersumber dari : & 63.431 .100 \\
\hline & a.Kredit (60\%) & 42.287 .400 \\
\hline & b.Dana BUMDes 40\%) & $\mathbf{3 4 . 7 6 0 . 0 0 0}$ \\
\hline II & 1.Kebutuhan Modal Kerja & 20.856 .000 \\
\hline & Dana modal kerja yang bersumber dari : & 13.904 .000 \\
\hline & a.Kredit (0\%) & 92.715 .810 \\
\hline III & b.Dana BUMDes (100\%) & 61.810 .540 \\
\hline & a.Kredit dana proyek yang bersumber dari: & $\mathbf{1 5 4 . 5 2 6 . 3 5 0}$ \\
\hline & b.Dana BUMDes & \\
\hline
\end{tabular}

Sumber: hasil olahan, 2019

Dengan demikian, potensi kredit investasi dan modal kerja yang diperoleh pengusaha adalah Rp. 92.715.810 yang dalam ketentuan bank yang dimaksud akan dikembalikan dalam jangka waktu tiga tahun dengan grass period 2 tahun. Lebih lanjut, tingkat suku bunga pinjaman yang berlaku di bank tersebut pada saat ini (Bank BRI, 2019) adalah 7\% per tahun sedangkan metode pembayaran angsuran bunga adalah efektif menurun. Angsuran pokok dan angsuran bunga diasumsikan dibayar setiap tahun pada akhir bulan. 
6. Produksi dan Pendapatan

Sebagaimana dijelaskan sebelumnya, proporsi minyak kelapa yang diperoleh dari bahan baku daging kelapa segar adalah sebanyak 30\%. Dengan asumsi bahwa pabrik telah menggunakan $100 \%$ dari kapasitas optimalnya yaitu 0,2 ton per hari daging kelapa segar, maka jumlah produksi minyak kelapa yang dihasilkan adalah 5.000 liter minyak kelapa per bulan atau 60 ton per tahun selama umur proyek.

Tabel 4.6 Proyeksi Produksi

\begin{tabular}{|c|c|r|r|r|r|}
\hline No & Uraian & Satuan & Jumlah/hari & \multicolumn{1}{|c|}{ Jumlah/bln } & \multicolumn{1}{c|}{ Jumlah/thn } \\
\hline \multicolumn{2}{|c|}{ Produk dan penjualan } & & & & \\
\hline \multicolumn{2}{|c|}{ Minyak } & & & & \\
\hline a. & Jumlah Produksi & $\mathrm{Kg}$ & 200 & 5.000 & 60.000 \\
\hline b. & Nilai Penjualan/liter & $\mathrm{Rp}$. & 23.000 .000 & 575.000 .000 & 6.900 .000 .000 \\
\hline \multicolumn{2}{|c|}{ Jumlah } & & 23.000 .000 & 575.000 .000 & 6.900 .000 .000 \\
\hline
\end{tabular}

Sumber: hasil olahan, 2019

\section{Analisis Finansial}

1. Analisis Aliran Kas

Berdasarkan analisis Cash flow (aliran kas) selama 5 tahun, dengan operasi pada lampiran table 3 diketahui bahwa selama periode tersebut posisi kas tidak pernah terjadi defisit kas. Pada awal tahun ke 3, seluruh investasi dari modal sendiri sebesar Rp. 105.718.500,00 dengan asumsi bunga $10 \%$ per tahun dapat dikembalikan sesuai dengan jadwal yang telah ditetapkan maksimal selama 4 tahun.

2. Kriteria Kelayakan Investasi

Dasar untuk menilai kelayakan suatu usulan proyek investasi dilakukan dengan menggunakan kriteria yang lazim digunakan dalam mengevaluasi layak dan tidak layaknya suatu proyek dijalankan. Kriteria yang digunakan dalam kajian ini adalah:

\section{a. NPV (Net Present Value)}

Berdasarkan perhitungan dengan menggunakan discount factor $10 \%$ terlihat pada lampiran table 4 diketahui bahwa usaha pabrikasi pengolahan VCO dapat menghasilkan NPV positif Rp.594.468.272,00 .Hal ini mengindikasikan bahwa usaha pabrikasi pengolahan VCO layak dilaksanakan. 
b. IRR (Internal Rate of Return)

Berdasarkan perhitungan IRR table 5 diperoleh IRR 63,44 \% lebih besar dari tingkat keuntungan yang diharapkan (20\%) atau suku bunga bank komersial (10\%). Hal ini mengindikasikan bahwa usaha pabrikasi pengolahan VCO layak dilaksanakan.

c. PBP (Pay Back Period)

Berdasarkan perhitungan, usaha pabrikasi pengolahan VCO menghasilkan 3 tahun, 4 bulan seperti terlihat pada table 6 Total investasi Rp.154.526.350,00 dengan umur ekonomis selama 5 (lima) tahun dapat dikembalikan melalui Cash flow/proceeds selama 3,4 tahun yang lebih pendek dari jangka waktu umur ekonomis proyek investasi. Hal ini mengindikasikan bahwa usaha pabrikasi pengolahan VCO layak dikembangkan.

d. PI (Profitability Index)

Berdasarkan analisis perhitungan PI table 7 dapat diketahui bahwa perbandingan antara nilai arus kas bersih yang akan datang dengan nilai investasi yang sekarang dilihat pada tahun ke satu sampai tahun ke lima diperoleh hasil nilai PI sebesar 4,8 artinya bahwa Investasi dinyatakan layak jika PI > 1. 4,8>1, maka investasi dikatakan 1

Tabel 4.7 Nilai LQ Luas Panen dan Rating Komoditi Subsektor Perkebunan di Kecamatan Batu Ampar Tahun 2019

\begin{tabular}{|c|c|c|c|c|c|c|c|}
\hline \multirow{2}{*}{$\mathrm{NO}$} & \multirow{2}{*}{$\begin{array}{l}\text { Komoditi } \\
\text { Perkebunan }\end{array}$} & \multicolumn{3}{|c|}{ Batu Ampar } & \multirow{2}{*}{ Rating } & \multirow{2}{*}{$\begin{array}{c}\text { Basis/Non } \\
\text { Basis }\end{array}$} & \multirow{2}{*}{ Ket } \\
\hline & & $\mathrm{Xi} / \mathrm{yi}$ & $\mathrm{X} / \mathrm{Y}$ & LQ & & & \\
\hline 1 & Karet & 0,008 & 0,013 & 0,656 & 3 & NonBasis & $\mathrm{LQ}<1$ \\
\hline 2 & Kelapa Dalam & 0,301 & 0,217 & 1,388 & 2 & Basis & $\overline{L Q>1}$ \\
\hline 3 & Kelapa Hibrida & 0,031 & 0,232 & 0,133 & 4 & Non Basis & $2 \mathrm{LQ}<1$ \\
\hline 4 & Kelapa Sawit & 0,642 & 0,125 & 5,132 & 1 & Basis & $\mathrm{LQ}>1$ \\
\hline 5 & Kopi & 0,017 & 0,289 & 0,058 & 5 & Non Basis & $\mathrm{LQ}<1$ \\
\hline 6 & Pinang & 0,001 & 0,040 & 0,029 & 6 & Non Basis & $\mathrm{LQ}<1$ \\
\hline
\end{tabular}

Sumber: Data Olahan 2019 
Dari hasil analisis basis berdasarkan LQ terlihat potensi bahwa kelapa dalam merupakan salah satu potensi yang dimiliki Kecamatan Batu Ampar dimana hasil menujukan bahwa kelapa dalam memiliki nilai basis LQ lebih besar dari 1 yaitu sebesar 1,388 .

\section{SIMPULAN}

Simpulan yang dapat ditarik dari hasil penelitian ini adalah:

Pembangunan industri VCO Di Kawasan Pedesaan Batu Ampar Kabupaten Kubu Raya merupakan usaha potensial dalam upaya hilirisasi potensi perkebunan kelapa dalam yeng memberikan memberikan multiplier effect dan nilai tambah baik dari aspek ekonomi, peningkatan lapangan pekerjaan, kesejahteraan masyarakat.

Hasil dari penelitian menunjukkan bahwa investasi yang dilakukan untuk industri VCO di Kecamatan Batu Ampar Kabupaten Kubu Raya memberikan gambaran bahwa investasi layak untuk dilakukan terlihat dari nilai Net Present Value (NPV) yang positif sebesar Rp.594.468.272,00 , nilai Internal Rate Of Return (IRR) lebih tinggi dari tingkat suku bunga $10 \%$ bahkan nilai harapan $20 \%$ yaitu sebesar $63,44 \%$, nilai Pay Back Periode (PBP) yang menunjukan hasil di bawah umur ekonomis 5 tahun industri yaitu sebesar 3 tahun 4 bulan dan nilai Profitabilitas Indeks (PI) yang menunjukan nilai diatas atau lebih besar dari 1 yaitu sebesar 4,8.

\section{DAFTAR PUSTAKA}

APCC. 2009. APCC Standards for Virgin Coconut Oil. https://coconutcommunity.org/viewpdf/apcc_quality_standards_for_coconut_produc $\underline{\text { ts/3 }}$ (diakses pada 16/6/2019)

Badan Pusat Statistik. (2019). Kecamatan Batu Ampar dalam Angka 2019. Kubu Raya: Bps.

Badan Pusat Statistik. (2019). Kubu Raya dalam Angka 2019. Kubu Raya: Bps.

Badan Pusat Statistik. (2019). Kalimantan Barat dalam Angka 2019. Pontianak: Bps.

Husnan, Suad and Suwarsono Muhammad. (2000). Studi Kelayakan Proyek. Edisi Keempat, Penerbit UPP AMP YKPN, Yogyakarta. 
Husein Umar. (2001). Riset Pemasaran dan Perilaku Konsumen. Jakarta: PT.Gramedia Pustaka Utama.

Husein, Umar. 1999. Studi Kelayakan Bisnis, Manajemen, Metode dan Kasus. PT. Gramedia Pustaka Utama. Jakarta.

Ibrahim, Yacob, H.M. 2009. Studi Kelayakan Bisnis, Edisi Revisi. PT. Rineka Cipta. Jakarta.

Kasmir dan Jakfar. 2009. Studi Kelayakan Bisnis. Kencana. Jakarta

Muta'ali, L. 2013. Pengembangan Wilayah Pedesaan Perspektif Keruangan Yogyakarta: BPFG UGM.

Nursyam, Marhawati, dan Alam. 2013 Analisis Titik Pulang Pokok Usaha Virgin Coconut Oil (VCO) Pada UKM Pengais Jaya Di Desa Ampibabo Kecamatan Ampibabo Kabupaten Parigi Moutong. 